\title{
Synthesis of barium ferrite, using barite mineral ore and a metallurgical waste
}

\section{Síntesis de la ferrita de bario, empleando mineral de barita y un residuo metalúrgico}

ROSALES-SOSA, Ma. Gloria ${ }^{*} \dagger$, GARCIA-YREGOI, Manuel', ROSALES-SOSA, Blanca Idalia' and SERVIN-CASTAÑEDA, Rumualdo"

\author{
'Universidad Autónoma de Coahuila. Carretera 57 Km 5, 25710, Monclova Coah. México \\ "Universidad Autónoma de Coahuila. Barranquilla S/N, Col. Guadalupe, Monclova Coah. México
}

ID $1^{\text {st }}$ Author: Ma. Gloria, Rosales-Sosa / ORC ID: 0000-0002-6654-3433, Researcher ID Thomson: S-4829-2018, CVU CONACYT ID: 63212

ID $1^{\text {st }}$ Author: Manuel, Garcia-Yregoi / ORC ID: 0000-0002-8710-6750, Researcher ID Thomson: S-5632-2018, CVU CONACYT ID: 322570

ID $2^{\text {nd }}$ Coauthor: Blanca Idalia, Rosales-Sosa / ORC ID: 0000-0002-2114-7779, Researcher ID Thomson: AAH-4622-2020 , CVU CONACYT ID: CVU 842319

ID $3^{\text {rd }}$ Coauthor: Rumualdo, Servin-Castañeda / ORC ID: 0000-0002-8655-2572, Researcher ID Thomson: S-4952-2018, CVU CONACYT ID: 45820

\section{Abstract}

Samples of barite mineral ore, were ground to a mesh of 250 , and then were subjected to a leaching stage with hydrochloric acid at different times, then; the leached barite mineral ore was subjected to a carbonation stage controlling different parameters such as $\mathrm{pH}$, temperature, time and speed of agitation. Finally, it was subjected to a sintering stage with the $\mathrm{Fe}_{2} \mathrm{O}_{3}$ precursor obtained from the waste powder of the steelmaking company's rolling process, in a temperature range of 1000 and $1200{ }^{\circ} \mathrm{C}$, for 12 and 24 times. The materials obtained are characterized by infrared spectroscopy (IR Spectroscopy), X-ray Diffraction (XRD) and Scanning Electron Microscopy (SEM).

Barite mineral, Ferrite, Carbonation

\section{Resumen}

Muestras de mineral de barita, fueron molidas hasta una malla de 250, luego fueron sometidas a una etapa de lixiviación con ácido clorhídrico a diferentes tiempos, posteriormente, el mineral de barita lixiviada se sometió a una etapa de carbonatación controlando diferentes parámetros tales como $\mathrm{pH}$, temperatura, tiempo y velocidad de agitación. Finalmente se sometió a una etapa de sinterización con el precursor del $\mathrm{Fe}_{2} \mathrm{O}_{3}$ obtenido del polvo de residuo del proceso de laminación de empresa siderúrgica en un rango de temperatura de 1000 y $1200{ }^{\circ} \mathrm{C}$, por tiempos de 12 y 24 horas. Los materiales obtenidos son caracterizados por espectroscopia infrarroja (Espectroscopía IR), Difracción de Rayos X (DRX) y Microscopía Electrónica de Barrido (MEB).

Mineral de barita, Ferrita, Carbonatación

Citation: ROSALES-SOSA, Ma. Gloria, GARCIA-YREGOI, Manuel, GARCIA-ROSALES Eber Manuel, ROSALESSOSA, Blanca Idalia and SERVIN-CASTANEDA, Rumualdo. Synthesis of barium ferrite, using barite mineral ore and a metallurgical waste. Journal of Research and Development. 2020. 6-17: 1-8.

\footnotetext{
* Correspondence to the Author (mrosales@uadec.edu.mx)

$\dagger$ Researcher contributing as first author.
} 


\section{Introduction}

A fundamental part of modern technology is made up of devices that use ferromagnetic alloys as components. Since the last decades of the last century, a remarkable development of these alloys has been achieved with new compositions and production methods that open unprecedented technological, economic and ecological perspectives due to high yields, economies of scale, possibility of weight and size reduction. and low environmental impact of the equipment that contains them. However, these materials are produced only in some developed countries. (Marcelo Pagnola, 2015).

Hexagonal (hard) ferrites are used to make permanent magnets, they have the general formula $\left(\mathrm{AFe}_{12} \mathrm{O}_{19}\right)$, they are low-density materials and have a high coercive field; The good magnetic properties of these materials are attributed to their high crystalline magnet anisotropy. A very important hexagonal ferrite is $\mathrm{BaFe}_{12} \mathrm{O}_{19}$, known under the trade name Ferroxdure.

Barium hexaferrites type $\mathrm{M}$, whose chemical formula is $\mathrm{BaFe}_{12} \mathrm{O}_{19}$, are one of the most widely used magnetic compounds in the world due to their ease of obtaining and their physical properties, such as: high resistivity, high coercivity, relative low magnetic saturation and high retentivity. Its crystalline structure is similar to that of the magnetoplumbite mineral (Mariño-Castellanos et al., 2016).

Those responsible for magnetic behavior are ferric ions, where not all ions have magnetization in the same direction. Of the 12 ions available per unit cell, 8 have a magnetic moment in one direction and 4 have a magnetic moment in exactly the opposite direction, resulting in only 8 ions contributing to the resulting magnetization. These ceramics have applications in generators, alternators and motors; its electronic uses are found in magnets for loudspeakers, telephone receivers, and in devices for closing doors and toys (Eduardo Camargo, 2011).
To obtain inorganic solid materials and in general when it comes to oxides, one of the most traditionally used procedures has been the socalled "ceramic method" (Gaona Jurado et al., 2007), which consists essentially of mixing compounds in the most homogeneous way possible precursors in stoichiometric amounts and subjecting said mixture to a heat treatment at high temperatures, so that a chemical reaction in the solid state takes place that originates the product sought.

Barium ferrite is usually obtained at an industrial level using the ceramic method, that is, by reacting $\mathrm{BaCO}_{3}$ and $\mathrm{Fe}_{2} \mathrm{O}_{3}$ at high temperatures, obtaining the $\mathrm{BaFe}_{12} \mathrm{O}_{19}$ ferrite.

The research for the synthesis and formation of barium ferrite has not stopped, as carried out by (Garcia Casillas et al., 2011), it is reported that by the chemical co-precipitation method, it obtained a precursor formed by iron and barium hydroxides and carbonates that when calcined at temperatures above $730{ }^{\circ} \mathrm{C}$, they were transformed into barium ferrite. He also practiced the microemulsion method, resulting in a fine precursor of iron and barium hydroxides and carbonates that, when calcined at temperatures above $760{ }^{\circ} \mathrm{C}$, becomes barium ferrite.

(Shao L. et al., 2018) I prepare compact hexagonal barium ferrite ceramics $\left(\mathrm{BaFe}_{12} \mathrm{O}_{19}\right)$ with excellent magnetic properties from powder with the optimal grain size, studied in detail the dependence of the microstructure and the magnetic properties of ceramics with powder grain size.

The single-phase hexagonal barium ferrite powder with a grain size of $177 \mathrm{~nm}, 256$ $\mathrm{nm}, 327 \mathrm{~nm}$ and $454 \mathrm{~nm}$ was obtained by calcination under different conditions. Scanning electron microscopy revealed that the $327 \mathrm{~nm}$ powder was beneficial in obtaining a homogeneous grain size and compact ceramic.

(Zhou E. et al., 2018) used two-pass sintering (TSS) which has been used to make hexagonal barium ferrite ceramics $\left(\mathrm{BaFe}_{12} \mathrm{O}_{19}\right)$ with high density and fine grain size. Densification, microstructure and magnetic properties were investigated. 
The sample prepared by the TSS process with the first step sintering temperature of 1325 ${ }^{\circ} \mathrm{C}$, the second step sintering temperature of $1300{ }^{\circ} \mathrm{C}$ and a retention time of 20 hours showed a density of $98.01 \pm 0.25 \%$ of the density theoretical $\left(5.29 \mathrm{~g} / \mathrm{cm}^{3}\right)$ and exhibited a uniform microstructure with a small average grain size $(2.92 \pm 0.05 \mu \mathrm{m})$. Using the TSS process they were able to obtain dense, fine-grained $\mathrm{BaFe} 12 \mathrm{O} 19$ ceramics with high saturation magnetization.

The latest research on barium ferrites has already reached advanced fields in nanotechnology, such as that reported by (Iqbal S. et al., 2019) where it investigated the use of barium ferrite nanoparticles for electromagnetic interference (EMI) which it is one of the main causes of the failure of electronic devices.

I perform a synthesis of barium ferrite nanoparticles $\left(\mathrm{BaFe}_{12} \mathrm{O}_{19}\right)$ using the sol-gel technique for an efficient application of EMI protection. These nanoparticles were annealed at $400{ }^{\circ} \mathrm{C}, 700{ }^{\circ} \mathrm{C}$ and $850{ }^{\circ} \mathrm{C}$ to investigate the effect of temperature on the protection efficiency and morphology of the $\mathrm{BaFe}_{12} \mathrm{O}_{19}$ nanoparticles.

The studies showed that the $\mathrm{BaFe}_{12} \mathrm{O}_{19}$ nanoparticles annealed at $850{ }^{\circ} \mathrm{C}$ exhibited a crystalline pure phase hexagonal structure with a high magnetic moment.

One reason for the impact of carrying out the project is the search for better synthesis methods for barium ferrites. In this project, the barite mineral was used for the synthesis of barium ferrite, since in the state of Coahuila there are large deposits of barite ore, mainly in the lagoon and coal mining region.

Another important reason arises from seeing the problem represented by the generation of large by-products of some companies in the town, in this case from the steel company, where $\mathrm{Fe}_{2} \mathrm{O}_{3}$ is obtained as a by-product with little rejection, it is proposed to study it for the formation of materials magnetic evaluating its properties with respect to the variant quality of $\mathrm{Fe}_{2} \mathrm{O}_{3}$. Regarding the iron oxide to be used, currently a steel company in the region recovers this compound as a by-product of the cold rolling mill around 100 tons per month, which has around $76 \%$ iron oxide.
In this work, the barite mineral $\left(\mathrm{BaSO}_{4}\right)$ was used, which was ground and leached with hydrochloric acid $(\mathrm{HCl})$, at three different times. Subsequently, the direct conversion method was used, from which the carbonation of barite in an aqueous medium was carried out using a solution of sodium carbonate $\left(\mathrm{Na}_{2} \mathrm{CO}_{3}\right)$ in stoichiometric ratio.

After obtaining the barium carbonate $\left(\mathrm{BaCO}_{3}\right)$, a calcination was carried out to obtain the barium oxide $(\mathrm{BaO})$, which combined with the ferric oxide $\left(\mathrm{Fe}_{2} \mathrm{O}_{3}\right)$ results in the formation of barium ferrite $\left(\mathrm{BaFe}_{12} \mathrm{O}_{19}\right)$.

The materials obtained are characterized by the analysis techniques of Infrared Spectroscopy (IR Spectroscopy), X-Ray Diffraction (XRD) and Scanning Electron Microscopy (MEB).

\section{Methodology}

To carry out the process of obtaining barium ferrite, it was necessary to transform the barium sulfate that contains the barite to barium carbonate, for which it was necessary to grind, leach and carbonate the barite mineral and subsequently it was carried out the ferretation of the material, in the calcination stage.

\section{A. Grinding}

In the barite ore grinding stage, a crusher and a ball mill, brand BICO Inc., were used in order to obtain a particle size of less than 250 meshes.

For the granulometric analysis, a ROTAP was used. For the determination of the sample weights, a Scientech SA120 digital analytical balance was used with an accuracy of ten thousandths after the decimal point.

\section{B. Leaching}

The main objective of leaching is the separation or elimination of impurities within the barite mineral, such as aluminum, titanium, sodium, strontium ions, etc. These impurities also called solutes contained in a solid phase, by contact with a liquid solvent selectively dissolves them, and may be a simple physical solution or a chemical reaction that frees the solute from the solid matrix. 
The solid-liquid leaching or extraction of the mineral was carried out with a mesh smaller than 250. The sample was 50 grams, which was placed in a $500 \mathrm{ml}$ Erlenmeyer flask, using 4, 6 and $8 \% \mathrm{HCl}$ as a leaching agent, in times of 5 , 10 and 15 minutes. They were subsequently filtered on Whatman No. 40 filter paper and washed with $10 \mathrm{ml}$ of hot distilled water. The filter paper with the sample was placed in a watch glass and the water was allowed to evaporate in a desiccator.

\begin{tabular}{|l|l|l|}
\hline Inogarnic acid & \multicolumn{1}{|c|}{ Concentration (\%) } & Time (min.) \\
\hline $\mathrm{HCl}$ & 4,6 and 8 & 5,10 and 15 \\
\hline
\end{tabular}

Table 1 System used for leaching

\section{Carbonation}

The dried sample was placed in a $500 \mathrm{ml}$ Erlenmeyer flask, with sodium carbonate (stoichiometric calculation determined for each of the samples plus $40 \%$ excess respectively) and $150 \mathrm{ml}$ of distilled water, this mixture was placed on a magnetic stirring brand CORNING Model PC-620 120 VAC-1113 Watts Hz at 870 RPM.

The variables that were controlled were the temperature of $90{ }^{\circ} \mathrm{C}$, the time of one hour and the $\mathrm{pH}$ of the reaction was kept between the values of 10 and 11 .

Samples of $3 \mathrm{ml}$ of the solution were taken at the times of $0,15,30,45$ and 60 minutes for the determination of the reacted fraction of the precipitated sulfate ion, for which the sample was placed in a $250 \mathrm{ml}$ beaker $25 \mathrm{ml}$ of distilled water, $1 \mathrm{ml}$ of concentrated hydrochloric acid $(\mathrm{HCl})$ and $2 \mathrm{ml}$ of $10 \%$ barium chloride and boiled in a Bunsen burner for 2 minutes, filtering the precipitate with Whatman No. 40 filter paper., which were previously weighed.

The obtained crystals were collected from the filtered solution. At the end of the reaction for one hour, the sample was filtered and placed in a watch glass in a desiccator, and then the efficiency of conversion of barium sulfate to barium carbonate was weighed and calculated, according to the following reaction:

$$
\mathrm{BaSO}_{4}+\mathrm{Na}_{2} \mathrm{CO}_{3} \longrightarrow \mathrm{BaCO}_{3}+\mathrm{Na}_{2} \mathrm{SO}_{4}
$$

\section{Calcination}

For the formation of barium ferrite, 0.1 mol (15.33299 gr) of barium oxide and $0.1 \mathrm{~mol}$ of ferric oxide (15.9687gr) were weighed from pickling flakes from the lamination process of a steel company, with a content of $87.25 \%$ of iron.

The homogenized mixture was divided into equal parts and placed in the previously weighed alumina crucibles. The crucibles were introduced into the muffle furnace at temperatures of 1000 and $1200{ }^{\circ} \mathrm{C}$, for times of 12 and 24 hours, waiting for the following reactions to occur:

$$
\begin{aligned}
& \mathrm{BaCO}_{3} \longrightarrow \mathrm{BaO}+\mathrm{CO}_{2} \\
& \mathrm{BaO}+6 \mathrm{Fe}_{2} \mathrm{O}_{3} \longrightarrow \mathrm{BaFe}_{12} \mathrm{O}_{19}
\end{aligned}
$$

This stage was carried out in a THERMOLYNE brand electric muffle (FURNACE 48000).

The chemical analysis of the barite mineral was performed by the Infrared Spectroscopy (IR) technique, in a Perkin Elmer 2000 FT-IR equipment.

A Bruker brand D8 ADVANCE X-Ray Diffractometer was used to determine the composition of the samples. The equipment was operated in a range of $2 \theta$ from 10 - 80 degrees, with an increase (step) of 0.020 degrees, with an increase in time (step time) of 1.2 seconds at a temperature of $25{ }^{\circ} \mathrm{C}$. For the interpretation of results Match 5.1 software was used. The microstructure and aspects related to the morphology of the powders obtained as reaction products were performed in a Philips XL30 ESEM Scanning Electron Microscope.

\section{Results}

The chemical analysis of the barite mineral with the Infrared technique gave the following results, $\mathrm{Zr} 0.004 \%$, Al $0.15 \%$, Ti $0.176 \%$, Na $0.282 \%$, Sr $0.614 \%$, S $8.333 \%$, Ca $9.587 \%$ and Ba $57.45 \%$, elements that are considered to be part of an expected composition of a barite mineral, which makes the barite mineral a good quality material to be used as a raw material for the synthesis of barium ferrite, since it contains a high percentage of barium, indicating that the amount of barium sulfate is high. 
Regarding the leaching of the mineral with $\mathrm{HCl}$, the $\mathrm{HCl}$ concentrations that were $4 \%$, $6 \%$ and $8 \%$ found that when increasing the concentration of the acid, the percentage of leaching is increased, that is, the best results were obtained in the $8 \%$ concentration as shown in Figure 1.

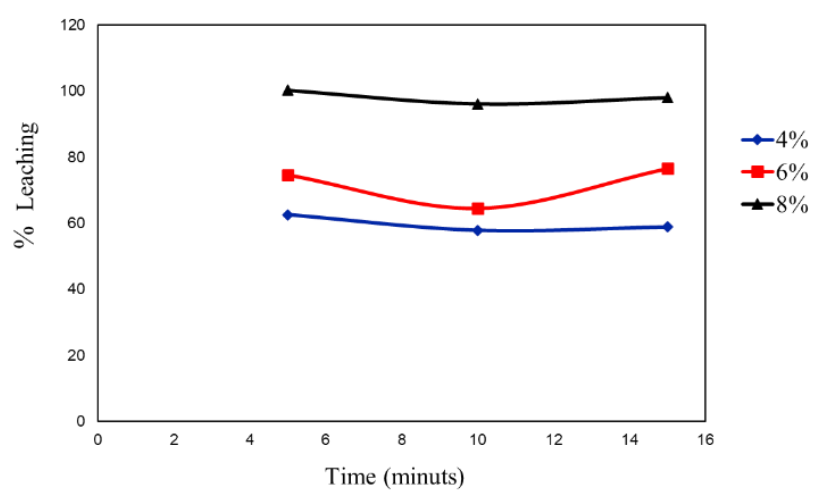

Figure 1 Leaching efficiency using hydrochloric acid as a leaching agent

Regarding the time, it was found that in all the concentrations of $4 \%, 6 \%$ and $8 \%$ of $\mathrm{HCl}$ they remain very stable in the three times of 5.10 and 15 minutes with the exception of the concentration of $6 \%$ of $\mathrm{HCl}$ at the time of 10 minutes where you see a reduction in leaching efficiency.

Figure 2 shows the diffractogram of the barite mineral after having been leached with $\mathrm{HCl}$, where we can see that most of the intensities correspond to the barium sulfate phase, according to the Match 5.1 software, corresponding to entry 96-900. -4486, said phase has an orthorhombic crystalline structure. Some intensities corresponding to the barium carbonate phase are also observed (entry 96-9006846).

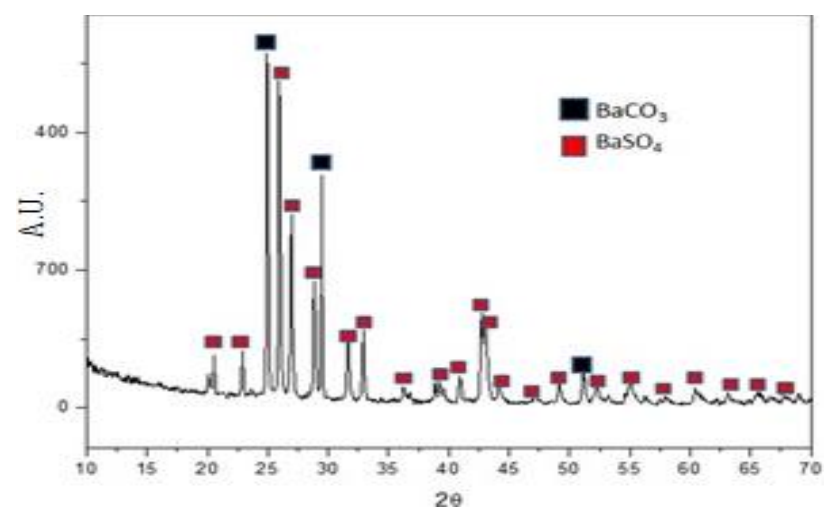

Figure 2 Barite ore diffractogram, leached with $8 \% \mathrm{HCl}$, for 15 minutes
There are no compounds of impurity elements, so we can say that the stage of leaching of the mineral was appropriate to eliminate some elements of impurity.

Regarding carbonation, Figure 3 shows the x-ray diffraction diffractogram, after the barite sample was carbonated with a $2 \mathrm{M}$ solution of $\mathrm{Na}_{2} \mathrm{CO}_{3}$. According to the results, it can be seen that there are more intensities corresponding to the barium carbonate phase, compared to the barite sample that was only washed with $\mathrm{HCl}$, which means that in the carbonation stage the elimination of large amount of sulfates, however there are some intensities corresponding to the barium sulfate phase.

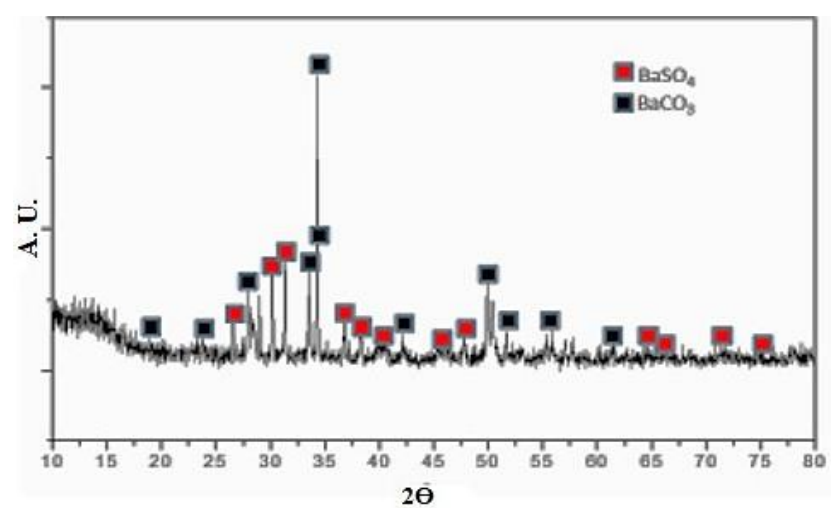

Figure 3 Diffractogram of the barite mineral sample leached with $8 \% \mathrm{HCl}$ and carbonated with $\mathrm{Na}_{2} \mathrm{CO}_{3} 2 \mathrm{M}$

Figure 4 shows the micrographs of the carbonated barite mineral powders in $2 \mathrm{M}$ $\mathrm{Na}_{2} \mathrm{CO}_{3}$ solutions, which were previously leached with $\mathrm{HCl}$. In it we can see bright white cubic particles, which are believed to correspond to the barium carbonate phase, but there are also other types of more opaque particles and in the form of different irregular plates, which could be barium sulfate particles. In general, isolated, scattered particles can be seen and some smaller regions show a certain degree of agglomeration, this behavior is due to the synthesis process of the same. The predominant size is $2 \mu \mathrm{m}$. The corresponding EDS (Energy Dispersion Spectrometry) shows us the presence of the elements barium, carbon and oxygen, which are the elements of the compound barium carbonate, so we can say that the carbonation process was indeed efficient, however, if it differs with respect to the analysis performed with $\mathrm{x}$-ray diffraction (XRD), which indicated the presence of the barium sulfate phase (Figure 3). 
The EDS did not detect sulfur, an explanation would be because it is a lighter element, however, it is believed that, if it is present in the form of sulfate, this is demonstrated by XRD and the different shape and hue of the particles found in the observed micrograph. in Figure 4.

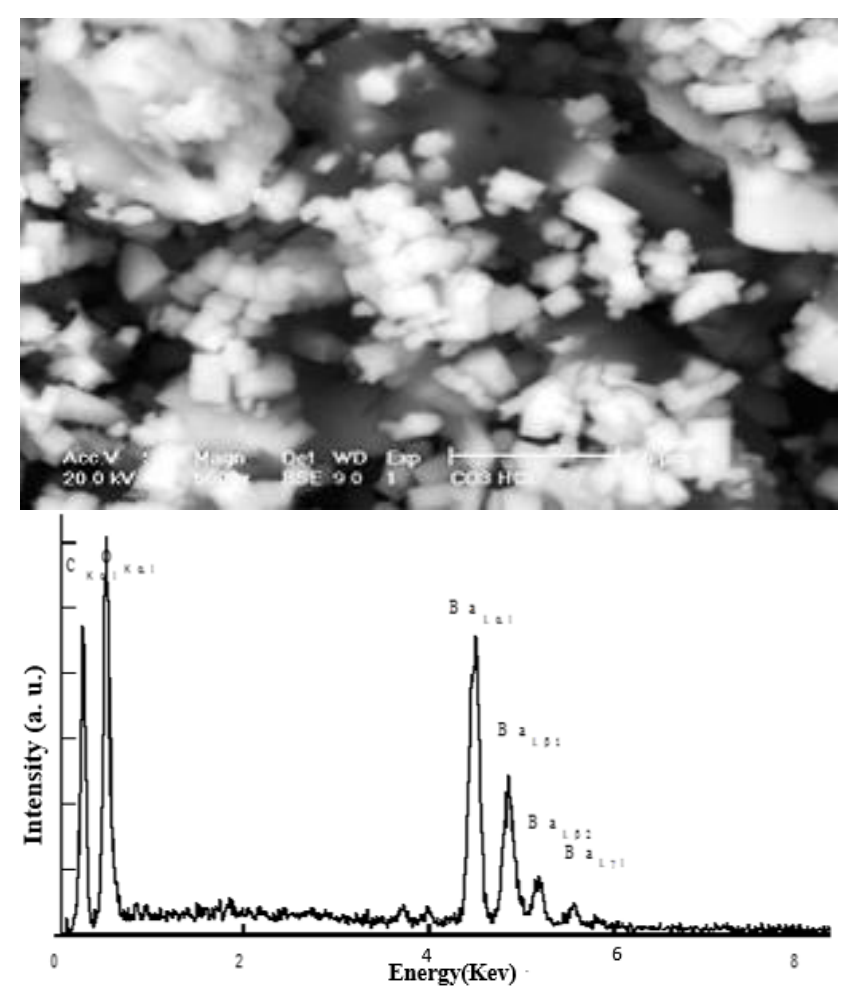

Figure 4 Micrograph and EDS of the carbonated barite powders in a $2 \mathrm{M}$ solution of $\mathrm{Na}_{2} \mathrm{CO}_{3}$

\section{$\mathrm{BaFe}_{12} \mathrm{O}_{19}$ synthesis}

Figure 5 shows the diffraction patterns of the products obtained when the samples were sintered at $1000{ }^{\circ} \mathrm{C}$ for 12 and 24 hours. According to these results, it was observed that if the desired compound was formed, barium hexaferrite, which means that all the barium carbonate present in the sample reacted with $\mathrm{Fe}_{2} \mathrm{O}_{3}$ from the steelmaking residue within 12 hours.

A very similar behavior was observed in the 24 hours reaction time. The new phase obtained was identified as $\mathrm{BaFe}_{12} \mathrm{O}_{19}$, according to Match 5.1 software, with entry number 96100-9033, corresponding to a hexagonal crystalline structure, with network parameter a or equal to $5.8890 \AA$ and c equal to $23.1820 \AA$.
However, as we can see, we also have the presence of barium sulfate, this phase, which was maintained after carbonation, remains after the sample has been sintered at high temperatures, which means that barium sulfate does not decompose at the temperature of 1000 and $1200{ }^{\circ} \mathrm{C}$, even when increasing the reaction time to 24 hours.

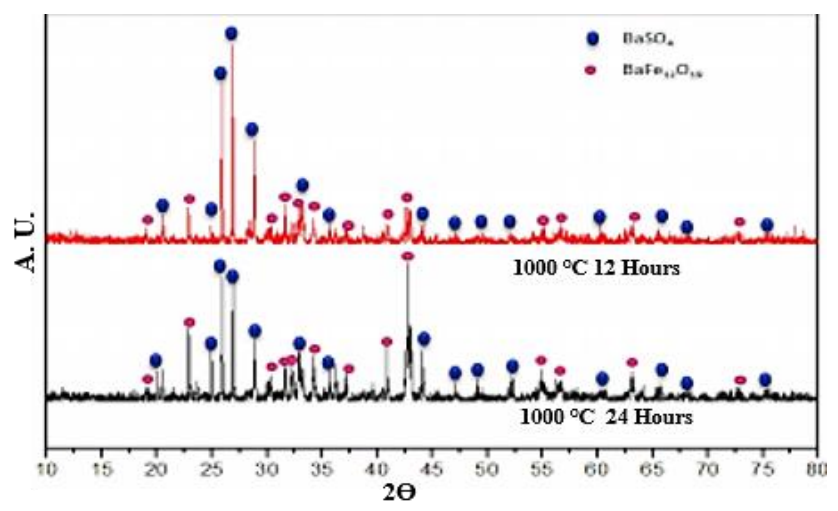

Figure 5 Diffraction patterns of the powders obtained by sintering the samples leached with $8 \% \mathrm{HCl}$ calcined at $1000{ }^{\circ} \mathrm{C}$ for 12 and 24 hours

Figure 6 shows the diffraction patterns of the sintered samples at a temperature of $1200{ }^{\circ} \mathrm{C}$. Barite samples leached with $8 \% \mathrm{HCl}$ and heated with $\mathrm{Fe}_{2} \mathrm{O}_{3}$ at a temperature of $1200{ }^{\circ} \mathrm{C}$ for 12 and 24 hours are compared. The presence of the intensities that in composition correspond to the $\mathrm{BaFe}_{12} \mathrm{O}_{19}$ phase can be observed in both samples, but the $\mathrm{BaSO}_{4}$ phase is also present, that is, they coexist in the two phases in the samples. Based on these results, a way would be sought for the ferrite, $\mathrm{BaFe}_{12} \mathrm{O}_{19}$, to have a higher crystallographic presence compared to $\mathrm{BaSO}_{4}$. To achieve this, to have a purer barium ferrite, the carbonation stage would have to be modified in the increase of the concentration of sodium carbonate and reaction time, in order to obtain greater purity of barium carbonate.

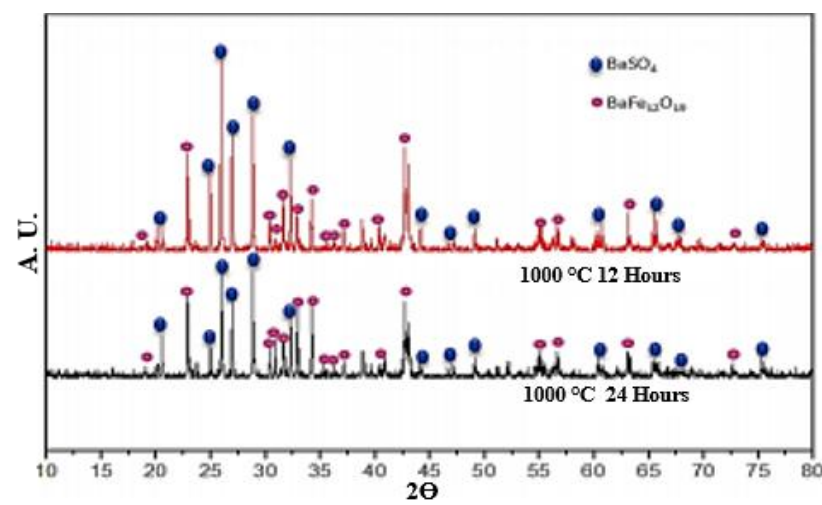

Figure 6 Diffraction patterns of barite samples leached with $8 \% \mathrm{HCl}$ and heated with $\mathrm{Fe}_{2} \mathrm{O}_{3}$ at a temperature of $1200{ }^{\circ} \mathrm{C}$ for 12 and 24 hours 
During the $1200{ }^{\circ} \mathrm{C}$ sintering step, the Barium Sulfate compound remains stable, because the decomposition reaction of barium sulfate to barium oxide would occur at a temperature of more than $1580{ }^{\circ} \mathrm{C}$.

The microstructural details associated with the morphology of the products of the synthesis of ferritic compounds, using the barite mineral as the initial precursor of the barium ion and rolling powder as a precursor of the iron ion, from a sintering above $1000{ }^{\circ} \mathrm{C}$, were evaluated after analysis of the structural changes determined by X-ray Diffraction.

Figure 7 shows the micrographs obtained when the mixture of barium carbonate and mill scale was sintered, at a temperature of $1200{ }^{\circ} \mathrm{C}$ for 12 hours of residence.

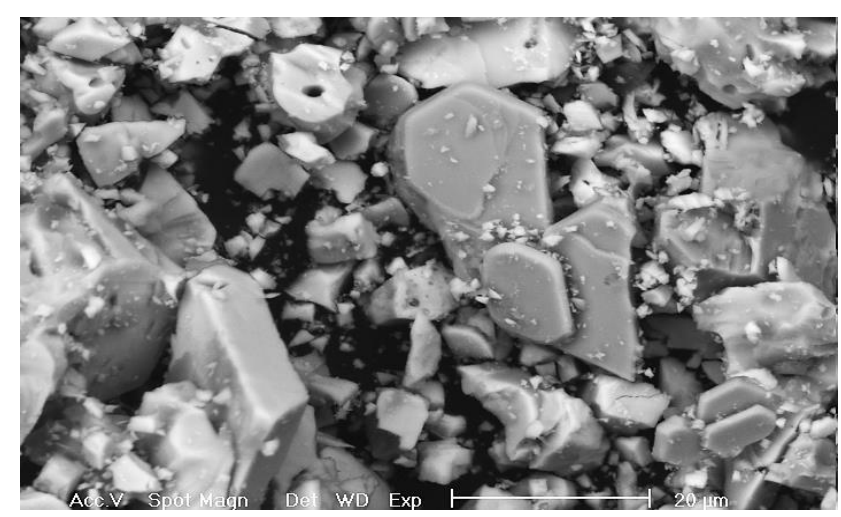

Figure 7 Micrographs of ferritic compounds obtained at a temperature of $1200{ }^{\circ} \mathrm{C}$ for 12 hours of reaction

According to the micrographs, it was determined that the growth of the particles of the new phase of $\mathrm{BaFe}_{12} \mathrm{O}_{19}$ occurs in the form of irregularly shaped plates. The presence of other smaller irregularly shaped particles on the plates is also observed, which could be treated of the barium sulfate phase.

Figure 8 shows the particles that in composition correspond to the compound $\mathrm{BaFe}_{12} \mathrm{O}_{19}$ obtained at a temperature of $1200{ }^{\circ} \mathrm{C}$ for 24 hours of reaction. This result is confirmed by observing the corresponding EDS, since it only indicates the presence of Barium, Oxygen and Iron. It can be assumed that, by increasing the reaction time, a greater diffusion of atoms occurs and the equilibrium sites of the barium hexaferrite phase are accommodated, since better defined plates are observed, these are observed in hexagonal forms, which is a growth typical of barium hexaferrite.
It can also be seen that, as the reaction time increases, a greater agglomeration of the particles occurs. Particles continue to be observed on the plates, most of which correspond to the barium sulfate phase, detected by x-ray diffraction.

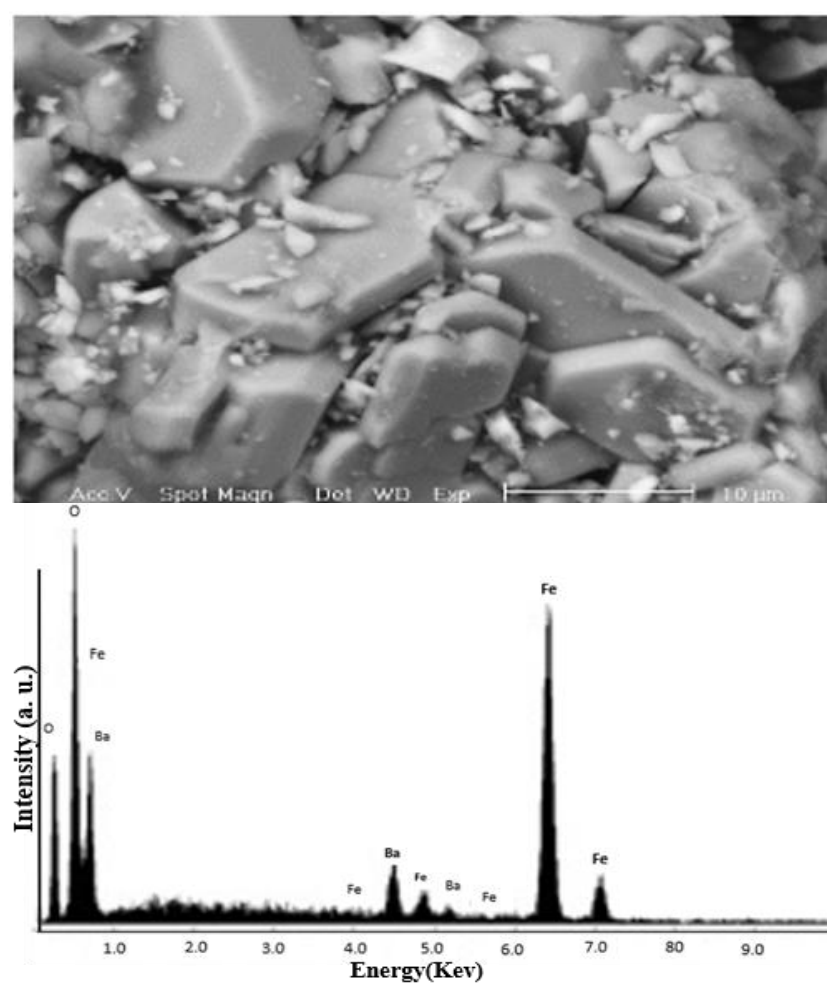

Figure 8 Micrographs and EDS of the ferritic compounds obtained at a temperature of $1200{ }^{\circ} \mathrm{C}$ for 24 hours of reaction

\section{Conclusions}

Hydrochloric acid is a good leaching agent because it removed many impurities from the barite mineral. The best result being found in a concentration of $8 \% \mathrm{HCl}$.

The barite mineral, leached with $8 \% \mathrm{HCl}$, for 15 minutes, was appropriate to remove some impurities.

Barite ore leached with $8 \% \mathrm{HCl}$ and carbonated with $2 \mathrm{M} \mathrm{Na} \mathrm{NO}_{3}$. It shows that during the carbonation stage the removal of a large amount of sulfates was achieved.

Micrographs of carbonate barite ore powders in $2 \mathrm{M} \mathrm{Na}{ }_{2} \mathrm{CO}_{3}$ solutions, previously leached with $\mathrm{HCl}$. Check that the carbonation stage occurred, but partially. The morphology of the powders was in cubic form with average particle sizes of $2 \mu \mathrm{m}$. 
In the calcination stage, with the barium precursors of the barite mineral and with the iron residue as a source of $\mathrm{Fe}_{2} \mathrm{O}_{3}$, the formation of the compound $\mathrm{BaFe}_{12} \mathrm{O}_{19}$ was favored at temperatures from $1000{ }^{\circ} \mathrm{C}$ in the time of 12 and 24 hours.

The barite leached with $8 \% \mathrm{HCl}$ and heated with $\mathrm{Fe}_{2} \mathrm{O}_{3}$ at a temperature of $1200{ }^{\circ} \mathrm{C}$ for 12 and 24 hours found the presence of $\mathrm{BaFe}_{12} \mathrm{O}_{19}$ and $\mathrm{BaSO}_{4}$.

The formation of the $\mathrm{BaFe}_{12} \mathrm{O}_{19}$ compound powders occurred in the form of plates, which are best observed at $1200{ }^{\circ} \mathrm{C}$ and 24 hours of reaction, the agglomeration of several particles in the form of plates of various sizes was found.

\section{References}

Camargo Zambrano E., (2011), Estudio comparativo de algunas ferritas obtenidas por el método citrato. Trabajo de tesis para Maestro en Ciencias Químicas.

Gaona Jurado S., Sandoval D., Caneiro A., (2007), Efecto de la ruta de Síntesis en la obtención de polvos cerámicos manométricos de hexaferritas de bario. Scientia et Techica, No. 36.

Garcia Casillas, Perla E. (2011). Estudio comparativo de las propiedades magnéticas de ferritas hexagonales de Bario obtenidas por los métodos de coprecipitación y microemulsión. Boletín de la Sociedad Española de Cerámica y Vidrio. 38.

Iqbal, S., Kotnala, G., Shah, J., Ahmad, S. (2019). Barium ferrite nanoparticles: A highly effective EMI shielding material. Materials Research Express.

Mariño-Castellanos, Pupo-Palma C., VegaGarcía A., Guerra-Dávila Y. (2016.) Correlación entre la microestructura de ferritas de bario tipo$\mathrm{M}$ dopadas con $\mathrm{Al}$ y $\mathrm{Co}$ y sus propiedades estructurales y magnéticas, Rev. Cubana Quím. Vol. 28, no. 1, e-ISSN 2224-5421.

Pangola M., Sirquen H., (2015), Materiales Magnéticos Modernos. Revista Petroquímica, petróleo, gas y energía número 315, año 33, ISSN 2469-0139.
Shao, L., Shen, S., Zheng, H. et al. (2018). Effect of Powder Grain Size on Microstructure and Magnetic Properties of Hexagonal Barium Ferrite Ceramic. Journal of Elec Materi 47, 4085-4089 (2018).

Zhou, E., Zheng, H., Zheng, L., Zheng, P., Ying, Z., Deng, J., Zhou, J. (2018). Synthesis of dense, fine-grained hexagonal barium ferrite ceramics by two-step sintering process. International Journal of Applied Ceramic Technology, 15(4), 1023-1029. 